\title{
PARATICINELLA N. GEN. AND TAXONOMIC REVISION OF TICINELLA BEJAOUAENSIS SIGAL, 1966
}

\author{
Isabella Premoli Silva ${ }^{1,4}$, Michèle Caron ${ }^{2}$, R. Mark Leckie ${ }^{3}$, Maria Rose Petrizzo $^{1}$, Dario Soldan ${ }^{1}$ And \\ DAVIDE VERGA ${ }^{1}$
}

\section{ABSTRACT}

Based on examination of the type material deposited by Jacques Sigal at the Musée National d'Histoire Naturelle in Paris, we have validated the hypothesis of Randrianasolo and Anglada (1998) that the holotype and paratype of Ticinella bejaouaensis Sigal 1966 belong to two different species, the distributions of which do not overlap. Indeed, the holotype is of late Albian age and from Madagascar whilst the paratype is of a latest Aptian age and from Tunisia. Sigal's paratype is here confirmed to be the holotype of the species eubejaouaensis Randrianasolo and Anglada, 1998. It displays a distinctive wall texture bearing perforation cones that coalesce to form irregularly arranged rugosities and ridges, which tend to parallel the periphery. In addition, flaps may cover the umbilical area. However, it lacks true umbilical supplementary apertures and therefore cannot be included in the genus Ticinella Reichel, 1950. The new genus Paraticinella, with Paraticinella eubejaouaensis as the type species, is here formalized to accommodate uppermost Aptian trochospiral individuals with a wall texture bearing perforation cones, rugosities, and ridges in patterns paralleling the margin, and possessing an umbilical cover-plate.

Paraticinella eubejaouaensis evolved from Hedbergella trocoidea in the upper Aptian. The evolutionary trend is exemplified by the increasing number of chambers, by flattening of the spire height, by widening of the umbilicus with the appearance of a cover-plate, by acquisition of welldeveloped ridges on wall surfaces, and by the appearance of weakly developed infralaminal accessory apertures in later specimens of $\boldsymbol{P}$. eubejaouaensis.

A close study of the holotype of Ticinella bejaouaensis Sigal, 1966 reveals a substantial similarity in morphology and wall structure with Ticinella roberti and a lack of distinguishing criteria between the two species. Consequently, the species Ticinella bejaouaensis is invalidated and is considered to be a junior synonym of $T$. roberti.

A third species was observed associated with Ticinella roberti and Biticinella breggiensis in Madagascar and Spain, and it is attributable to the genus Ticinella based on the presence of true umbilical supplementary apertures and a typical Ticinella wall structure (muricate to coarsely pustulose), while in gross morphology, it resembles Paraticinella eubejaouaensis. We have named this new taxon Ticinella moulladei. It differs from $T$. roberti by its thinner test, more numerous chambers, and wider umbilicus.

\footnotetext{
${ }^{1}$ Department of Earth Sciences “A. Desio," University of Milan, Via Mangiagalli 34, 20133 Milano, Italy.

${ }^{2}$ Département de Géosciences, Géologie et Paléontologie, University of Fribourg, Chemin du Musée, 1700 Fribourg, Switzerland.

${ }^{3}$ Department of Geosciences, University of Massachusetts, $611 \mathrm{~N}$. Pleasant St., Amherst, MA 01003, U.S.A.

${ }^{4}$ Correspondence author. E-mail: isabella.premoli@unimi.it
}

Finally, the last zone of the uppermost Aptian must be renamed the Paraticinella eubejaouaensis Zone to replace Ticinella bejaouaensis, which is now considered to be an invalid taxon.

\section{HISTORICAL BACKGROUND}

The taxon bejaouaensis was identified as a new variety of Ticinella roberti (Gandolfi, 1942) by Sigal in 1966, who did not provide a full description and instead described only the characters for distinguishing it from $T$. roberti as follows (translation from French): "This form of rather large size differs from the species by the rather high number of chambers, around 9, and their much more rugose surface; the last half whorl comprises more than 4.5 chambers; the spiral side shows a rather loose coiling mode. These characters are somewhat variable: up to 10.5 or 11 chambers in the last whorl suggesting an evolute aspect; moreover, as in the species the spiral side may vary from planar to slightly concave. The coiling appears dextral based on the few specimens observed; the average size is $0.45 \mathrm{~mm}$ in diameter and $0.22 \mathrm{~mm}$ in thickness." Therefore, according to Sigal (1966), T. roberti var. bejaouaensis differs from $T$. roberti s.s. by having a larger size test, a greater number of chambers, a more rugose surface, a larger umbilicus, and a slower rate of chamber size increase.

Sigal (1966) clearly stated that the type level of the holotype (Diego well, $215.2 \mathrm{~m}$, Madagascar) is very low in the Albian, while the paratype (Djebel Bejaoua, Tunisia) is from latest Aptian-age strata. He plotted a short range for Ticinella bejaouaensis from the uppermost Aptian to the lowermost range of Ticinella primula in the lower Albian. It was very unfortunate that Sigal did not follow the rules of zoological nomenclature by choosing a paratype from a different level as well as a different locality and thereby created the potential for subsequent taxonomic misinterpretations.

Moullade (1966) first elevated Sigal's variety to the species level, stating that Ticinella bejaouaensis is a different species from $T$. roberti and that there is no stratigraphic continuity between the highest occurrence of $T$. bejaouaensis and the lowest occurrence of $T$. roberti. In support of his assumption, Moullade (1966) provided a new, more exhaustive description (emendation) of $T$. bejaouaensis (translation from French): "it possesses generally 8-9 chambers, occasionally more, and a large but rather shallow umbilical depression; labial lamellar extensions are well developed and fused in a large umbilical plate; intraumbilical supplementary apertures are gradually acquired through its stratigraphic range." Moullade (1966) also mentioned that, compared to $T$. roberti, $T$. bejaouaensis has a thinner test in side view, the wall texture is finer $(T$. roberti has a wall texture similar to that of Biticinella 


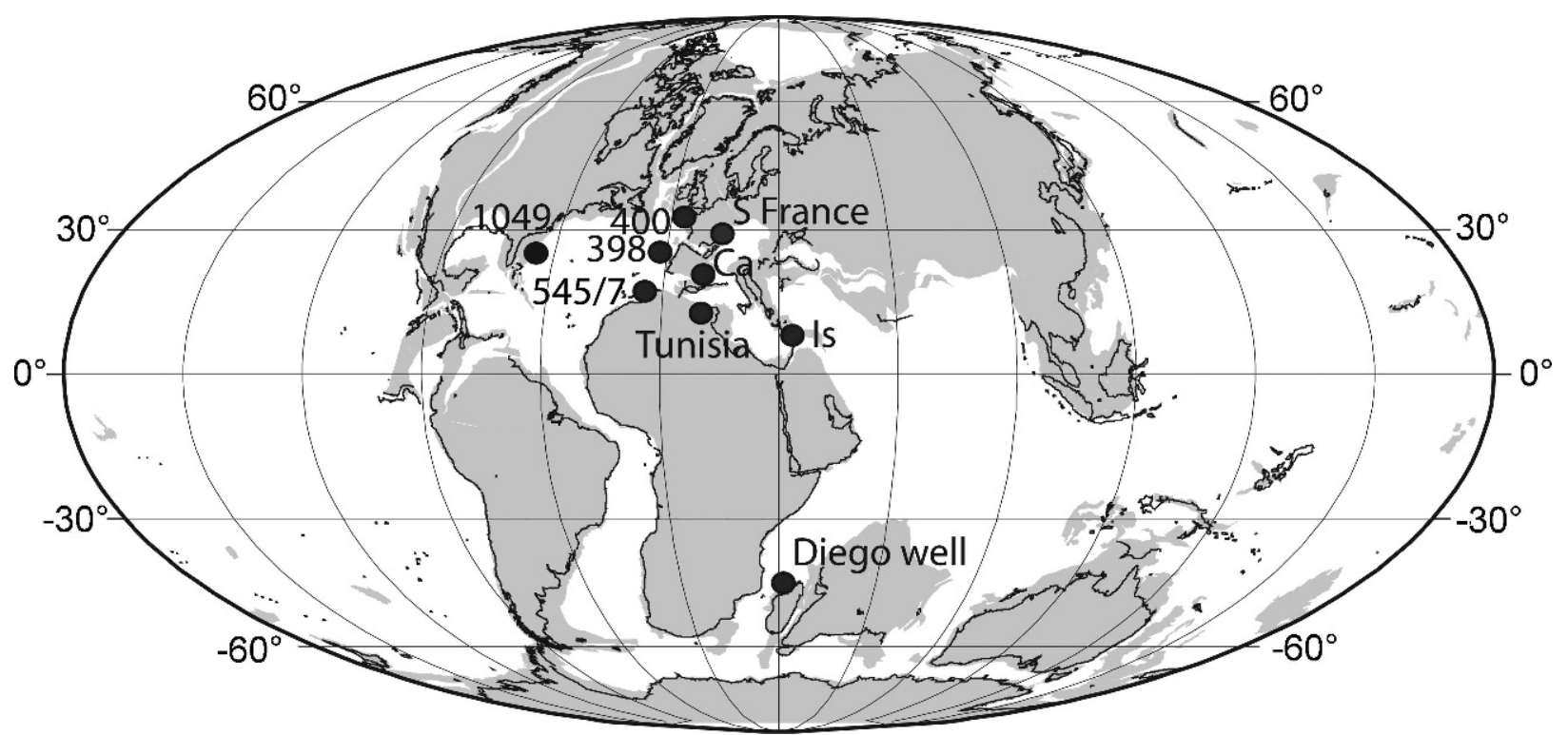

FIgURE 1. Location map of the main localities mentioned in this study. Paleogeographic reconstruction for 101 Ma, late Albian, after Hay and others (1999). S France = Vocontian basin; $\mathrm{Ca}=$ Caravaca, southeastern Spain; Is = Yam borehole, Israel; $398=$ DSDP Site 47/2-398, Vigo Seamount, Iberia; $400=$ DSDP Site 48-400, Bay of Biscay; 545/7 = DSDP Sites 79-545 and 547, off Morocco; $1049=$ ODP Hole 171B-1049, the Blake Nose, off northern Florida; Diego well, Madagascar.

breggiensis), the perforations are smaller, the umbilicus is larger and shallower, labial lamellar extensions are more developed, and rugosities are confined to the inner whorls unlike in $T$. roberti (see wall texture discussion in later section). While Moullade (1966) described the supplementary apertures in $T$. roberti as supralabial and more "rotaliporiform," recalling those in the species Rotalipora ticinensis and Rotalipora appenninica (now attributed to the genera Pseudothalmanninella and Parathalmanninella, respectively; see Lipson-Benitah, 2008), he stated that "the supplementary apertures observed in bejaouaensis...[are due to the incomplete fusion] of the rims pertaining to two successive lamellar expansions resulting" in a weakly developed infralaminal (not supralabial) aperture. He also stated that $T$. bejaouaensis in general differs from Ticinella praeticinensis by lacking pinching at the chamber margin. According to Moullade (1966), the stratigraphic range of $T$. bejaouaensis is also constrained to the uppermost Aptianlowermost Albian as reported by Sigal (1966).

Collignon and others (1979) revised the Diego well (Madagascar) biostratigraphy and in doing so revised the age of the type level of the Ticinella bejaouaensis holotype to the earliest late Albian, as supported by the associated planktonic foraminiferal species, including Biticinella breggiensis. However, in this assemblage, Sigal (in Collignon and others, 1979) could not identify T. bejaouaensis (described and illustrated as $T$. cf. bejaouaensis) with certainty and suspected there was not a continuous record between the latest Aptian-earliest Albian and late Albian forms.

On the basis of Sigal's suspicion and the discrepancy in age of the type levels of the Ticinella bejaouaensis holotype and paratype, Randrianasolo and Anglada (1998) reached the conclusion that the holotype and paratype of Sigal's bejaouaensis belong to two different species and erected the new species eubejaouaensis for the latest Aptian-earliest
Albian forms. However, in their short note (devoid of illustrations), these authors did not provide an exhaustive description of the differences between Sigal's holotype and paratype, and they failed to precisely state which of Sigal's figures is the holotype of their new species.

Bellier and Moullade (2002, p. 19-20) and Moullade and others (2002, p. 138-139) provided new insights into this problem. First, they specified the correct figures of the holotype of the species eubejaouaensis Randrianasolo and Anglada, 1998 (= Sigal's 1966 paratype, plate V, figs. 8-9), and, second, they agreed with Randrianasolo and Anglada (1998) in considering the taxon eubejaouaensis (= Sigal's paratype, Djebel Bejaoua, Tunisia) as a valid species different from T. bejaouaensis Sigal, 1966. Moullade and others (2002) also supported the emended description of $T$. bejaouaensis by Moullade (1966), who definitely described Sigal's paratype, as the valid description for the species eubejaouaensis of Randrianasolo and Anglada, 1998. In addition, Moullade and others (2002, p. 139; see also Bellier and Moullade, 2002, p. 20) posed the question: if the upper Albian holotype of T. bejaouaensis Sigal, 1966 is a discrete taxon different from $T$. roberti, should it be considered an "objective junior synonym" of the latter?

The purpose of this paper is to provide an exhaustive description of the aforementioned taxa in order to validate or invalidate them and possibly better specify their distribution through time. It is worth mentioning that Sigal (1977) introduced T. bejaouaensis as the index species for identifying the uppermost zone of the Aptian, extending it across the Aptian/Albian boundary. Sigal's concept of the T. bejaouaensis Zone was maintained in all subsequent zonal schemes until today, although most zonal schemes limit the range of the nominate taxon to the uppermost Aptian (i.e., Caron, 1985; Bralower and others, 1995; Premoli Silva and Sliter, 1999; Leckie and others, 2002). 


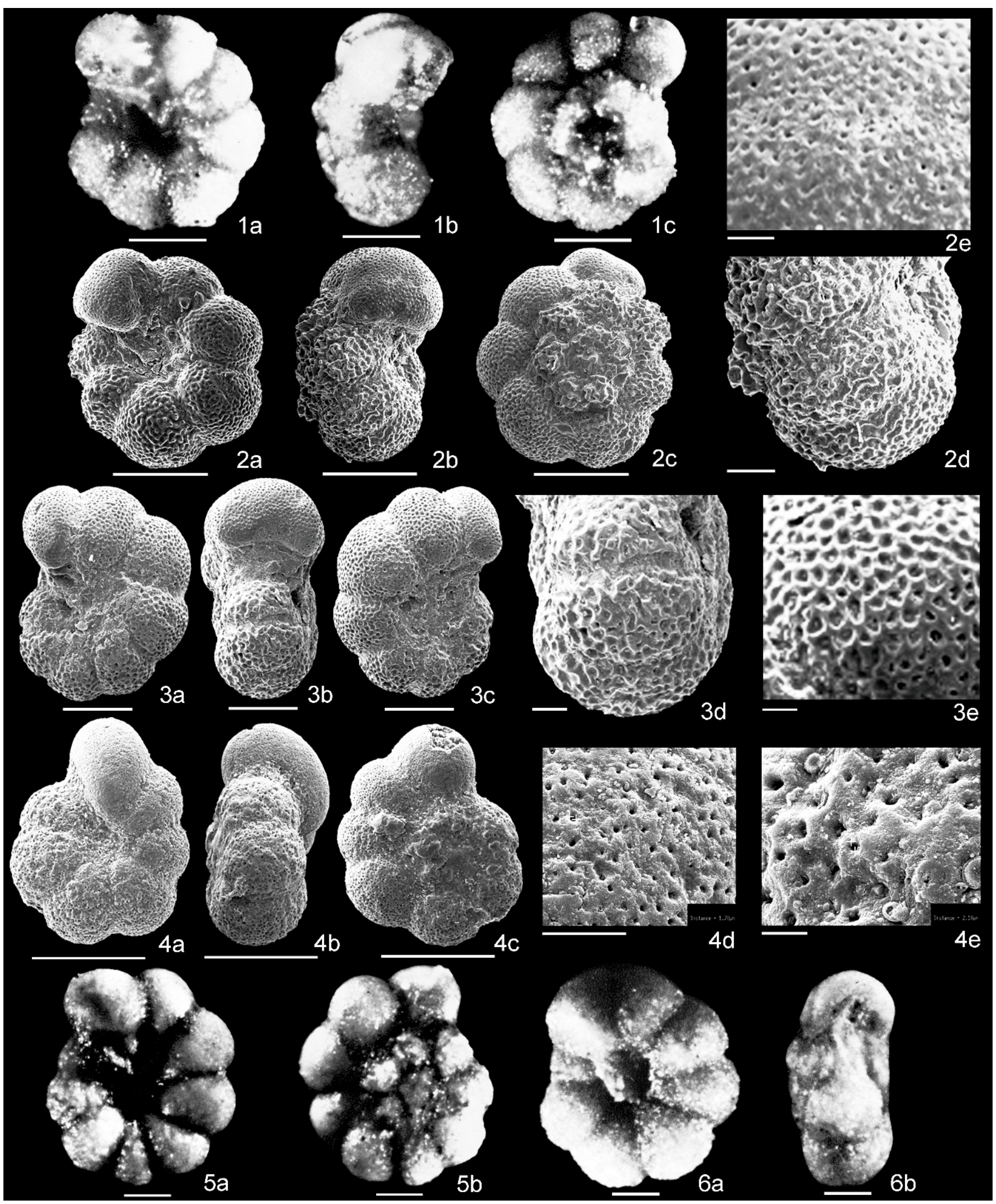

PLATE 1

1a-c Ticinella bejaouaensis Sigal, 1966, holotype, Diego well (Madagascar), core 56, level $215.2 \mathrm{~m}$ (light micrographs reproduced from Sigal, 1966, pl. V, figs. 5-7), early late Albian. Scale bars $=100 \mu \mathrm{m}$. 2a-e Ticinella roberti (Gandolfi, 1942), Diego well (Madagascar), core 53, level 200.0 m, Sigal's slide 1, case 15, late Albian; 2d, close-up of the edge view in $\mathbf{2 b} ; \mathbf{2 e}$, close-up of the last chamber in $\mathbf{2 b}$. Scale bars: $\mathbf{2 a}-\mathbf{c}=200 \mu \mathrm{m} ; \mathbf{2 d}=25 \mu \mathrm{m}$; $\mathbf{2 e}=12 \mu \mathrm{m}$. 3a-e Biticinella breggiensis (Gandolfi, 1942), DSDP Site 79-547-69-1, $50 \mathrm{~cm}$, late Albian; 3d, close-up of the edge view in 3b; 3e, close-up of the penultimate chamber in 3c. Scale bars: 3a-c $=200 \mu \mathrm{m} ; \mathbf{3 d}=50 \mu \mathrm{m} ; \mathbf{3 e}=25 \mu \mathrm{m}$. 4a-e Hedbergella trocoidea (Gandolfi, 1942). DSDP Site 79- 


\section{MATERIALS AND METHODS}

In the context of the Mesozoic Planktonic Foraminifera Working Group project, two of us (IPS and MC) had the opportunity in 2006 to examine the original specimens of Sigal (1966) deposited at the Musée National d'Histoire Naturelle in Paris. Unfortunately, because of the Museum's curatorial policy, the holotype and paratype of $T$. bejaouaensis could not be photographed with a scanning electron microscope (SEM).

Besides the holotype and paratype, we examined Sigal's original microslides of the holotype level of $T$. bejaouaensis (Sigal, 1966) from the Diego well at $215.2 \mathrm{~m}$, among others, deposited in 1979 by Sigal at the Geological Institute of the University of Fribourg (Switzerland) along with Sigal's original hand-written notes. Sigal's original material (microslide 4, case 9), included seven specimens identified as $T$. bejaouaensis by Sigal; from those, we picked the two best-preserved specimens that appeared close to Sigal's concept of bejaouaensis, along with two specimens of $T$. roberti (Sigal's microslide 1, cases 14 and 15, the Diego well, depth $200.0 \mathrm{~m})$. All of them have been micrographed with an SEM (see Plates 1, 2, and 3). In addition, for the purpose of this revision, we obtained SEM images of two specimens from upper Aptian strata of Ocean Drilling Program (ODP) Hole 1049C (ODP Leg 171B, the Blake Nose off northern Florida), and we re-studied the upper Aptian succession recovered at Deep Sea Drilling Project (DSDP) Site 545 (DSDP Leg 79, off Morocco) from Section 79-54551-3 up to Section 79-545-42-3. Additional SEM figures of specimens identified as T. bejaouaensis by the authors have been scanned from the literature to supplement the record of the wall features and textures of the involved taxa (Fig. 1).

\section{TAXONOMIC IMPORTANCE OF WALL TEXTURE AND TYPES OF ADDITIONAL APERTURES}

SEM study of the investigated material, originally included in the species bejaouaensis, demonstrates that the specimens of latest Aptian age do not share the same wall structure with the specimens of late Albian age. More specifically:

1. The wall surface of the uppermost Aptian forms, attributable to the species eubejaouaensis according to Randrianasolo and Anglada (1998) and Moullade and others (2002), is densely perforated by small pores ranging from 1.0 to $1.5 \mu \mathrm{m}$ and is covered by perforation cones in the early chambers of the last whorl (Pl. 2, Figs. 1d, 3) as in Hedbergella trocoidea (Pl. 1, Figs. 4d-e; Pl. 2, Fig. 8d). The volcano-like perforation cones may coalesce and overgrow to form irregular imperforate ridges that may mask the small, dense perforations. The ridges typically form patterns paralleling the coiling direction of the inner spire and the equatorial outline.

2. The late Albian T. roberti (see Pl. 1, Figs. 2a-e; Pl. 3, Figs. 6a-c), type species of the genus Ticinella, possesses a thick, strongly encrusted wall, similar to that of Biticinella breggiensis (Pl. 1, Figs. 3a-e) with large, regularly spaced perforations, as already noticed by Moullade (1966). In particular, its wall surface is coarsely pustulose in the inner spire and early chambers of the last whorl due to single pointed muricae growing into very irregularly distributed, larger pustules of different size surrounding the pores, rarely coalescing to form very short, randomly distributed, irregular ridges, and becoming gradually smoother in the last two or three chambers; perforations are rather large, ranging from 4 to $8 \mu \mathrm{m}$ and similar in size to those of the other ticinellids.

Individuals displaying the eubejaouaensis-type of wall also possess a rather large, shallow umbilical area that may be covered by well-developed flaps merging in a cover-plate and one to two (when visible) infralaminal accessory apertures bordered by a thin rim (Pl. 2, Fig. 6). By contrast, the specimens associated with the roberti-type of wall have poorly developed portici (no flaps) and a smaller, deep umbilical area into which open at least two, true supplementary apertures, each bordered by a rim (Pl. 1, Fig. 2a).

Based on these observations, the uppermost Aptian taxon, now equated to the species eubejaouaensis, is confirmed to be not conspecific with $T$. bejaouaensis, and furthermore it cannot be included in the genus Ticinella Reichel, 1950, emend. Brönnimann and Brown, 1956 (see also Verga, 2004). Therefore, we formalize the new genus Paraticinella to accommodate the trochospiral individuals that (1) have a wall texture of perforation cones, as found on upper Aptian finely perforate hedbergellids such as $H$. trocoidea, that coalesce to form irregular ridges that parallel the coiling direction, (2) possess an umbilical cover-plate, and (3) lack true supplementary apertures.

\section{FORMAL DESCRIPTION}

$$
\text { Genus Paraticinella n. gen. }
$$

Type species. Ticinella eubejaouaensis Randrianasolo and Anglada, 1998, and Ticinella bejaouaensis as emended by Moullade, 1966

Etymology. Similar to Ticinella.

Description. Low trochospiral, generally slightly lobate in outline, numerous chambers (7-11) in the last whorl, globular, sutures straight and depressed on both sides; wall finely perforate; wall surface rugose to smooth, with

$\leftarrow$

545-48-7, $23 \mathrm{~cm}$, late Aptian; 4d, close-up of the last chamber in $\mathbf{4 a}$; $\mathbf{4 e}$, close-up of the second chamber of last whorl in $\mathbf{4 a}$. Scale bars: $\mathbf{4 a}-\mathbf{c}=100$ um; $\mathbf{4 d}=20 \mu \mathrm{m} ; \mathbf{4 e}=10 \mu \mathrm{m}$. 5a-b Paraticinella eubejaouaensis (Randrianasolo and Anglada, 1998), holotype (= T. bejaouaensis paratype, Sigal 1966, pl. V, figs. 8-9), Djebel Bejaoua, Tunisia, latest Aptian. Scale bars $=100 \mu \mathrm{m}$, light micrographs; 5a $=$ umbilical view; 5b $=$ spiral view. 6a-b Paraticinella eubejaouaensis (Randrianasolo and Anglada, 1998), southeastern France (light micrographs reproduced from Moullade 1966, pl. 9, figs. 4-5, identified as Ticinella bejaouaensis), latest Aptian. Scale bars $=100 \mu \mathrm{m} ; \mathbf{6} \mathbf{a}=$ umbilical view; $\mathbf{6 b}=$ edge view. $\mathrm{a}=$ umbilical view; $\mathrm{b}=$ edge view, $\mathrm{c}=$ spiral view, except when specified. 


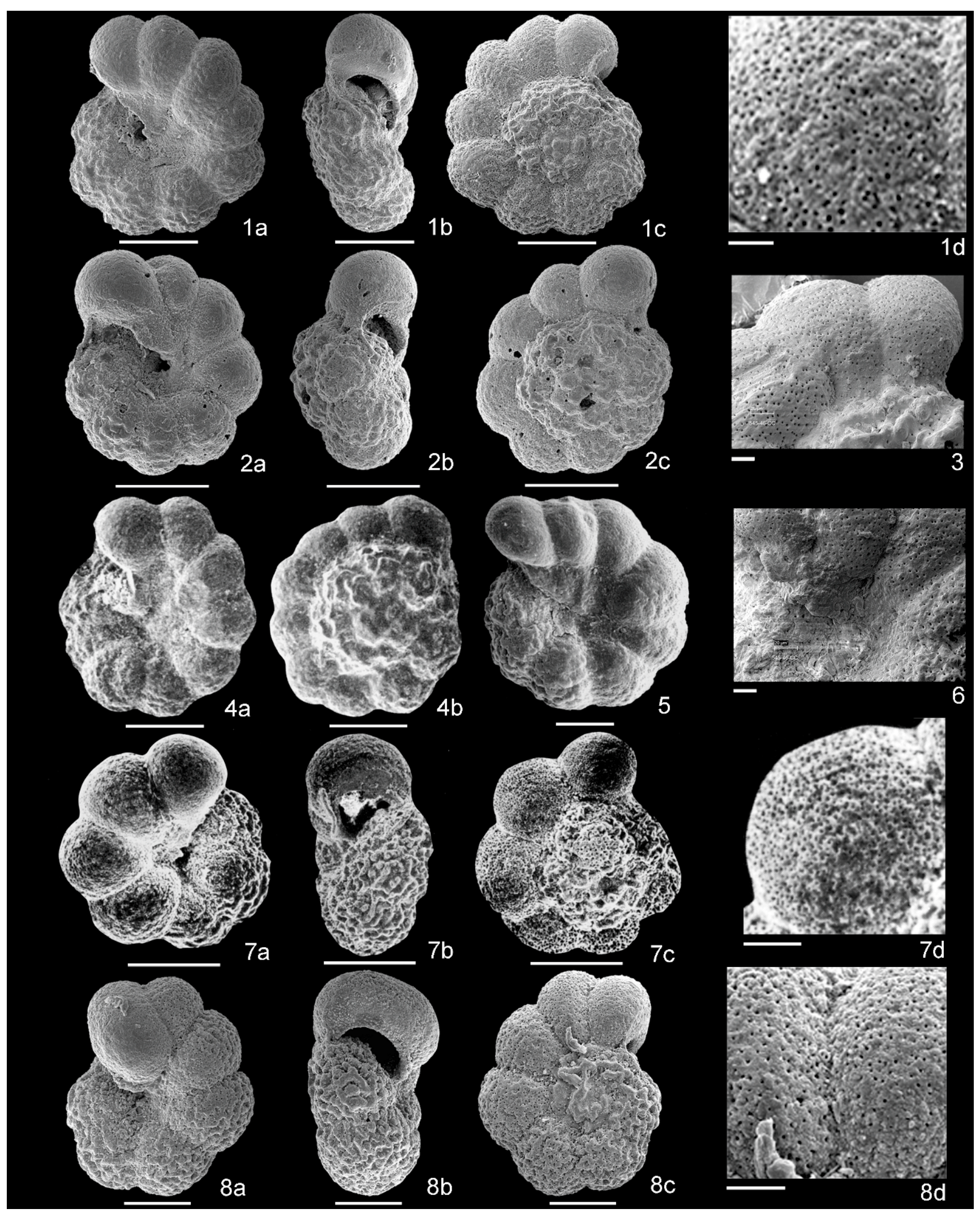

PLATE 2

1a-d Paraticinella eubejaouaensis (Randrianasolo and Anglada, 1998), ODP Hole 1049C-12-6, 62-64 cm, latest Aptian; 1d, close-up of the penultimate chamber in 1c with dense small pores and incipient perforation cones. Scale bars: 1a-c $=200 \mu \mathrm{m} ; \mathbf{1 d}=25 \mu \mathrm{m}$. 2a-c Paraticinella eubejaouaensis (Randrianasolo and Anglada, 1998), ODP Hole 1049C-12-6, 62-64 cm, latest Aptian. Scale bars = $200 \mu \mathrm{m}$. 3 Paraticinella eubejaouaensis (Randrianasolo and Anglada, 1998), DSDP Site 79-545-46-CC, latest Aptian. Close-up of the finely perforate surface of the last two 
rugosities masking the inner whorl, then covering the first chambers of the last whorl, frequently organized in irregularly sized ridges that may cover the pores and run parallel to the spiral suture; surface of later-formed chambers may bear volcano-like perforation cones that progressively attenuate toward the ultimate chamber; shallow umbilical area moderate to large in size; umbilical area may be covered, at least partially, by large flaps from the ultimate and penultimate chambers that fuse along a slightly depressed line forming a cover-plate; primary aperture an interiomarginal arch, umbilical-extraumbilical extending toward the periphery; may have one to two small, weakly developed umbilical accessory (infralaminal) apertures in the last chambers.

Distinguishing features. Paraticinella n. gen. is highly convergent in morphology with true Ticinella. The major differences between these two genera are wall textures: presence of perforation cones that coalesce to form irregular imperforate ridges paralleling the coiling direction in finely perforate Paraticinella, instead of single muricae and absence of any ridge patterns as in normally perforate Ticinella; and lack of true umbilical supplementary apertures in the new genus.

Remarks. Paraticinella differs from the genus Ticinella in having the wall surface covered by smaller pores and perforation cones that coalesce to form irregular imperforate ridges on earlier chambers and toward the periphery that may mask the small, dense perforations and that may grow as ridges in patterns paralleling the coiling direction of the inner spire and the equatorial outline; evolutionarily advanced specimens contain well-developed flaps merging into a cover-plate and may contain one to two weakly developed infralaminal accessory apertures bordered by a thin rim. In Ticinella, rugosities on the wall surface form from pointed muricae that grow as irregularly distributed larger pustules surrounding large perforations, and there are at least two well-developed supplementary apertures bordered by rims in the umbilical area, which may remain open or lightly covered by weakly developed portici. It is worth mentioning that Longoria (1974, p. 93) re-emended the genus Ticinella Reichel 1950, emended Brönnimann and Brown 1956, in order to summarize the characters he used for distinguishing Ticinella bejaouaensis Sigal.

Stratigraphic range. Uppermost Aptian; the extension into the lowermost Albian, as reported in the literature (i.e., Moullade, 1966; Sigal, 1966; Moullade and others, 2002), cannot be proven in the absence of the formal definition for the base of the Albian stage (Aptian/Albian boundary).

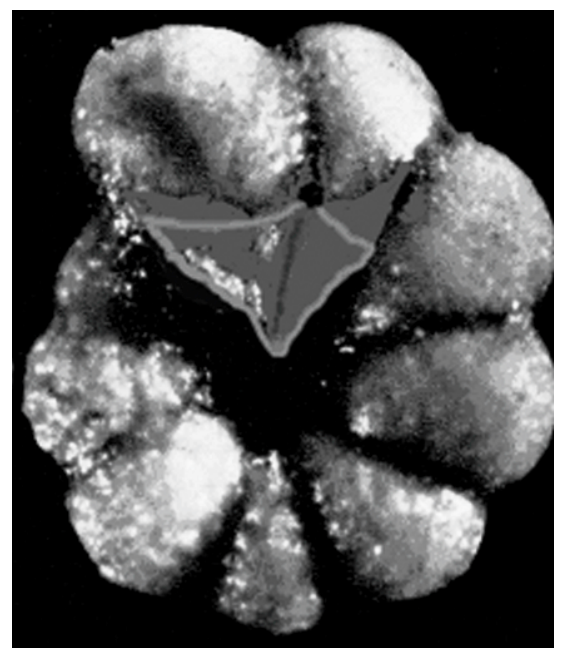

FIgURE 2. Umbilical view of the paratype of Ticinella bejaouaensis (light micrograph reproduced from Sigal, 1966, pl. V, fig. 9), now the holotype of Paraticinella eubejaouaensis (Randrianasolo and Anglada, 1998, emended Moullade, 1966), showing the labial flaps (gray shade) of the last two chambers covering the umbilical area as observed and drafted at the stereomicroscope (courtesy of Marie-Thérèse VénecPeyré), also illustrated on Plate 1, Figure 5a. The flaps are slightly depressed in the middle and bordered by slightly elevated thin rims (lighter lines); the darker line marks the slightly depressed junction between the two fused flaps. The black spot at the proximal end of the flap suture may mark a possible accessory opening.

\section{Paraticinella eubejaouaensis (Randrianasolo and Anglada,} 1998)

Text Fig. 2; Fig. 3, numbers 3-6; Pl. 1, Figs. 5a-b, 6a-b; Pl. 2, Figs. 1a-d, 2-6

Holotype. = paratype of Ticinella bejaouaensis Sigal, 1966, pl. V, figs. 8-9, microslide F6 0887, case 12, MNHN in Paris. From Djebel Bejaoua, Tunisia, late Aptian.

Ticinella bejaouaensis Sigal, 1966 in Moullade, 1966, emend., p. 103, pl. 9 , figs. 4-5.

Ticinella bejaouaensis Sigal in Longoria, 1974, p. $94-95$ (pars), pl. 18, figs. 1-2; pl. 19, figs. 9-16; pl. 21, figs. 12-13.

Ticinella roberti s.1. (Gandolfi) in Leckie, 1984, p. 600-601, pl. 5, figs. $5-12$, non pl. 5, figs. $1-4$.

Ticinella eubejaouaensis Randrianasolo and Anglada, 1998, p. 298.

Ticinella bejaouaensis Sigal in Aguado and others, 1999, fig. 10, p. 24 27.

Ticinella bejaouaensis Sigal in Lipson-Benitah and Almogi-Labin, 2000, p. 12, pl. 1, figs. 1, 3-5, not fig. 2.

Ticinella eubejaouaensis Randrianasolo and Anglada in Bellier and Moullade, 2002, p. 19-20, pl. 1, figs. 13-15.

"Hedbergella" aff. Ticinella bejaouaensis Sigal in Sigal, 1979, pl. 3, figs. 14-15.

$\leftarrow$

chambers, same specimen as in Figure 3, number 3 (spiral view). Scale bar $=20 \mu \mathrm{m}$. 4a-b Paraticinella eubejaouaensis (Randrianasolo and Anglada, 1998), DSDP Site 47B-398-104-2, 9-11 cm (reproduced from Sigal, 1979, Pl. 3, figs. 14, 15, identified as "Hedbergella" aff. Ticinella bejaouaensis), late Aptian. Scale bar $=100 \mu \mathrm{m} ; \mathbf{4 a}=$ spiral view; $\mathbf{4 b}=$ umbilical view. 5 Paraticinella eubejaouaensis (Randrianasolo and Anglada, 1998), Yam borehole, Israel, 3069-3075 m depth (reproduced from Lipson-Benitah and Almogi-Labin, 2000, Pl. 1, fig. 4, identified as Ticinella bejaouaensis), latest? Aptian. Umbilical view. Scale bar $=100 \mu \mathrm{m}$. 6 Paraticinella eubejaouaensis (Randrianasolo and Anglada, 1998), DSDP Site 79-545-46-CC, latest Aptian. Close-up of the umbilical area with two apparent small infralaminal accessory apertures, as in specimen on Figure 3, number 3 (umbilical view). Scale bar $=20 \mu \mathrm{m}$. 7a-d Hedbergella trocoidea (Gandolfi, 1942), DSDP Site 48-400A-68-1, 72-73 cm (reproduced from Dupeuble, 1979, Pl. 2, figs. 1-3, identified as Hedbergella (Ticinella) bejaouaensis), late Aptian; 7d, close-up of the surface of the penultimate chamber of 7c, showing the perforation cones. Scale bars: 7a-c $=100 \mu \mathrm{m} ; \mathbf{7 d}=25 \mu \mathrm{m}$. 8a-d Hedbergella trocoidea (Gandolfi, 1942), ODP Hole 1049C-12-6, 62-64 cm, late Aptian; 8d, closeup of the finely perforate surface of the last two chambers. Scale bars: $8 \mathbf{a}-\mathbf{c}=100 \mu \mathrm{m} ; \mathbf{8 d}=25 \mu \mathrm{m}$. $\mathbf{a}=$ umbilical view; $\mathbf{b}=$ edge view; $\mathbf{c}=$ spiral view, except when specified. 
New description of Sigal's paratype. Test a low, almost flat trochospire, 9 globular chambers in the outer whorl, increasing very gradually in size, separated by radial straight depressed sutures throughout on both sides; the last chamber is slightly displaced toward the umbilicus; in edge view, chambers globular in shape; wall surface rugose except in the last three chambers, with distinctive rugosities concentrated on the inner spire and on both sides of the first chambers of the last whorl, forming an irregular network of short ridges paralleling the equatorial periphery, gradually attenuating in the last four chambers; on the early chambers, there are perforation cones visible at high magnification with the stereomicroscope; primary aperture an interiomarginal low-medium arch, umbilical-extraumbilical in position; in the last two chambers, two large triangular labial flaps extend over the umbilicus; their surface is slightly depressed in the middle and slightly raised at the margin as a gentle rim readily visible, especially in the last one; the two flaps are fused, but the suture line, slightly depressed, remains visible; two small depressions filled with sediment, apparently in correspondence with the sutures, may mark the location of two small infralaminal openings (see Fig. 2).

Remarks. The paratype of $T$. bejaouaensis is flatter and definitely possesses a different wall structure compared to the holotype. Specifically, the paratype has a wall surface covered by short irregular ridges formed by coalescing perforation cones that are typically parallel to the periphery of the early chambers of the final whorl. This texture does not occur on the wall surface of the $T$. bejaouaensis holotype, which is covered by rugosities consisting of fused pointed muricae to very irregularly distributed, larger pustules (see following). At the species level, Paraticinella eubejaouaensis is markedly flatter and less compact (less embracing chambers) than the holotype of $T$. bejaouaensis.

Evolution of Paraticinella eubejaouaensis in DSDP Site 545. Sigal (1966) and Moullade (1969) suggested that the species eubejaouaensis evolved from Hedbergella trocoidea in the upper Aptian. This relationship was supported by Longoria (1974), who, in addition, identified transitional forms as the subspecies transitoria. We cannot adequately evaluate the status of this subspecies.

In order to further illustrate the evolution of the species eubejaouaensis, we re-studied the upper Aptian succession recovered at Site 545 (DSDP Leg 79, off Morocco) from Section 545-51-3 up to Section 545-42-3. We observed a clear evolutionary trend from Hedbergella trocoidea to eubejaouaensis: the chambers become more numerous, the spire height flattens, the test becomes thinner in edge view, and the umbilicus widens. Specifically, the appearance of larger, eight-chambered specimens with well-developed ridges on the wall surface is a critical benchmark for the recognition of eubejaouaensis. Early forms of such 8chambered eubejaouaensis have a thick test in edge view (see Pl. 5, figs. 11-12 in Leckie, 1984) and the species becomes progressively thinner and flatter up-section (Leckie's Pl. 5, figs. 5-6, 7-8, and 9-10 show this stratigraphic trend). This is further well illustrated in Figure 3 herein. The primary aperture has rather consistent features with readily visible labial flaps in all stages covering the umbilicus, while accessory apertures are rarely developed, even in well-preserved material. The new SEM photographs shown in Figure 3 reveal the gradual development through time of short and irregular ridges that progressively parallel the periphery in the early chambers of the outer whorl. This is best observed in edge and umbilical views. Pore size measured from all specimens ranges from 1.0 to $1.5 \mu \mathrm{m}$, which means the wall is finely perforate.

In addition, the study of DSDP Site 545 samples reveals that $P$. eubejaouaensis is highly variable; many specimens in a sample show transitional features with its ancestor $H$. trocoidea. In fact, near the topmost Aptian (near the end of the range of $P$. eubejaouaensis), specimens with as few as 7 chambers, possessing a thin, flat test with umbilical flaps, and typically ridged wall (Fig. 3, number 6), coexist with specimens having 8-9 chambers, a thicker test with moderate spire, and possessing a well-developed ridged wall but lacking well-developed umbilical flaps. In summary, the diagnostic features of $P$. eubejaouaensis are (1) typically $8-10$ chambers in the final whorl (as few as 7 and as many as 11 are also possible if specimens possess other diagnostic characteristics), (2) a finely perforate wall surface with perforation cones that become fused to form well-developed ridges (rugosities) typically parallel to the periphery of the early chambers of the final whorl, and (3) a moderate to wide umbilicus, often but not always with umbilical flaps. Within an individual assemblage, there can be a range of morphologies from specimens with a flat spiral side and wide umbilicus to specimens with the ultimate (and penultimate) chamber(s) extending into the umbilicus giving the impression of a higher spire.

Paraticinella eubejaouaensis is distinguished from $H$. trocoidea by having (1) a generally larger test size, (2) generally more numerous chambers, typically $8-10$, while $H$. trocoidea typically has $6.5-7.5$, (3) less embracing chambers, (4) a smaller ultimate chamber (H. trocoidea often has a relatively large final chamber that extends into the umbilicus), (5) a wider umbilicus, often possessing umbilical flaps (the aperture in $H$. trocoidea occasionally is bordered by a thin lip), and (6) well-developed, short ridges (rugosities) parallel to the periphery of the early chambers of the final whorl (see Pl. 2, Figs. 1a-c), a feature that is lacking in $H$. trocoidea, the wall surface of which is characterized by the presence of randomly distributed perforation cones that are larger in the early chambers but do not coalesce to form ridges (P1. 2, Fig. $8 \mathrm{a}-\mathrm{c})$.

Additional occurrences. Sigal (1979, P1. 3, figs. 14-15) illustrated a specimen from DSDP Leg 47B Site 398 that he identified as "Hedbergella" aff. Ticinella bejaouaensis Sigal, 1966 because of the numerous chambers; however, the absence of true supplementary apertures typical of the genus prevented him from identifying the specimen as Ticinella. A scanned enlargement of Sigal's Figure 15 (see P1. 2, Fig. 4a herein) shows a long flap covering the umbilicus, but no visible infralaminal apertures. In addition, the test surface is covered by ridges parallel to margin. These features allow us to attribute Sigal's specimen to $P$. eubejaouaensis, even though the perforation cones are not visible due to the poor preservation of the specimen. Moreover, a number of specimens that closely resemble Sigal's paratype of Ticinella bejaouaensis have been well 

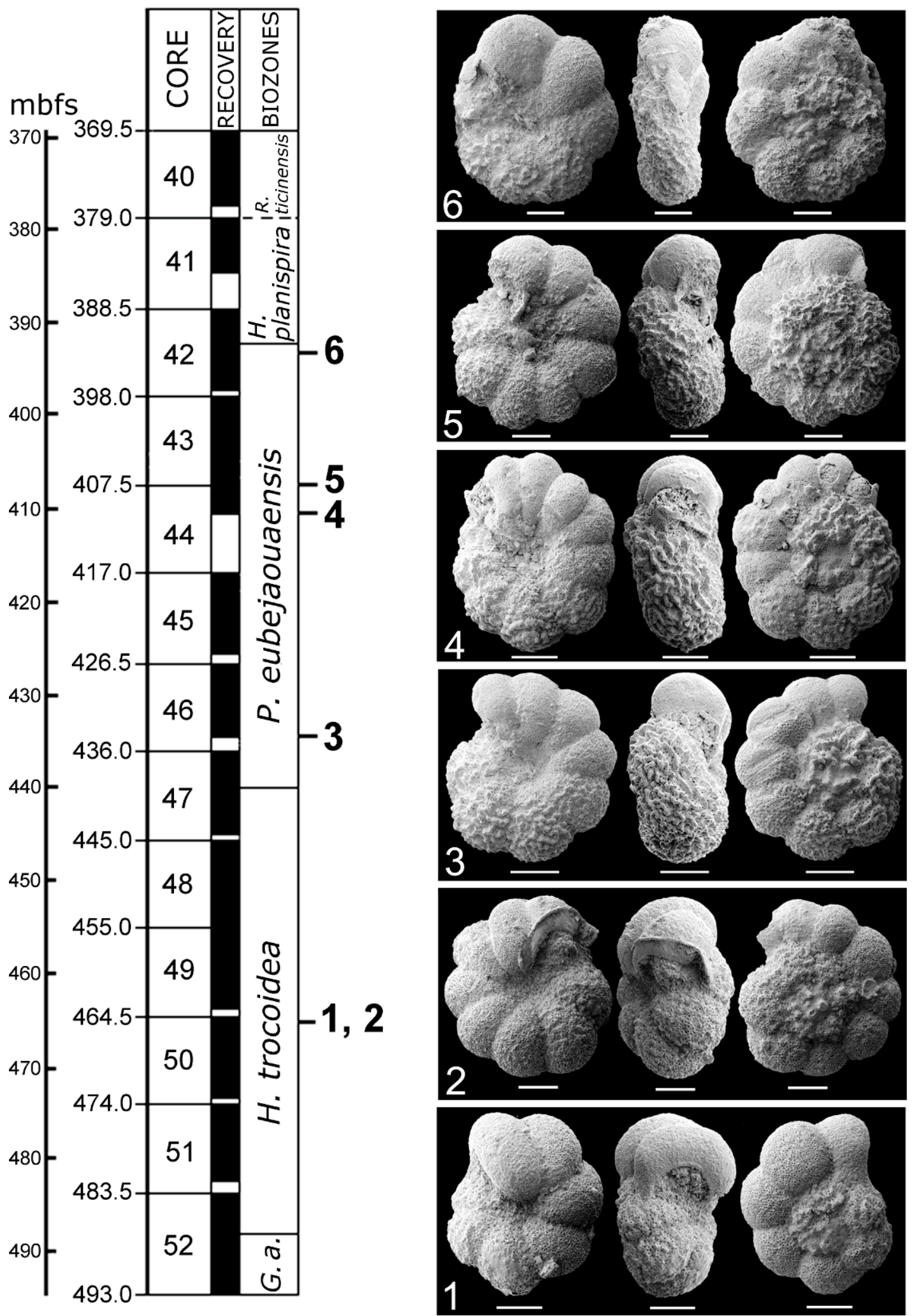

Figure 3. Evolution of Paraticinella eubejaouaensis (Randrianasolo and Anglada, 1998), at DSDP Leg 79, Site 545, off Morocco, plotted against core $\log$ with recovery (from Hinz and others, 1984, modified) and planktonic foraminiferal zones (after Leckie and others, 2002). 1. Hedbergella trocoidea, Sample 545-50-1, 33 cm. 2. H. trocoidea, Sample 545-50-1, 33 cm. 3. P. eubejaouaensis, Sample 545-46-CC. 4. P. eubejaouaensis, sample 545-44-CC. 5. P. eubejaouaensis, Sample 545-43-CC. 6. P. eubejaouaensis, Sample 545-42-3, $75 \mathrm{~cm}$. Scale bars $=100 \mu \mathrm{m}$; left $=u m b i l i c a l$ view; center $=$ side view; right $=$ spiral view. G.a. $=$ Globigerinelloides algerianus Zone; H. $=$ Hedbergella; $P .=$ Paraticinella $;$ R. $=$ Rotalipora . 


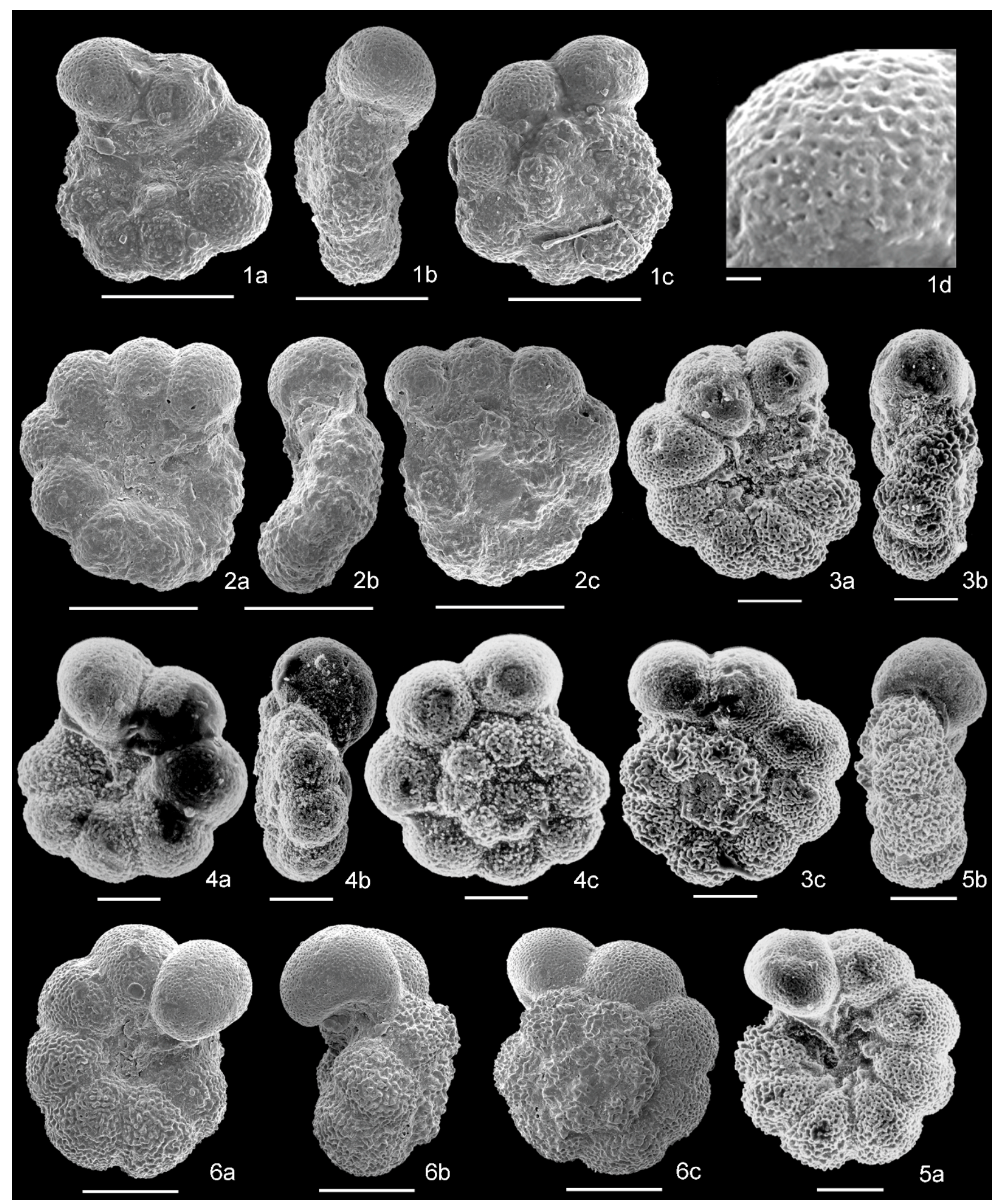

PLATE 3

Ticinella moulladei, new species. 1a-d Ticinella moulladei, n. sp., holotype, Sigal's original slide 4, case 9, Diego well (Madagascar), core 56, level $215.2 \mathrm{~m}$, identified by Sigal as Ticinella bejaouaensis, late Albian; 1d, a close-up of the penultimate chamber in 1a. Scale bars: $\mathbf{1 a}-\mathbf{c}=200 \mu \mathrm{m} ; \mathbf{1 d}=$ $12 \mu \mathrm{m}$. 2a-c Ticinella moulladei, n. sp., paratype, Sigal's original slide 4, case 9, Diego well (Madagascar), core 56, level 215.2 m, identified by Sigal as Ticinella bejaouaensis, late Albian. Scale bars $=200 \mu \mathrm{m}$. 3a-c Ticinella moulladei, n. sp., Caravaca, southeastern Spain, sample All 69.127 (printed from MC negatives), late Albian. Scale bars $=100 \mu \mathrm{m}$. 4a-c Ticinella moulladei, n. sp., Caravaca, southeastern Spain, sample All 69.127 (new reprint 
illustrated and described in several papers (i.e., Moullade, 1966; Longoria, 1974; Leckie, 1984; Aguado and others, 1999; Lipson-Benitah and Almogi-Labin, 2000; Bellier and Moullade, 2002). Morphologically, they match the emended description of Moullade (1966) for T. bejaouaensis (= description of $T$. eubejaouaensis; see Moullade and others, 2002). Several of these figures clearly show that perforation cones up to the antepenultimate chamber cover the wall surface. In addition, for the purpose of this revision, we obtained SEM photographs of two specimens from ODP Hole 1049C, here illustrated in Plate 2, Figures $1 \mathrm{a}-\mathrm{d}$ and $2 \mathrm{a}-\mathrm{c}$. In both specimens, the labial flaps of the last three to four chambers almost totally cover the large umbilicus (Pl. 2, Figs. 1a, 2a). The labial flaps are fused along gently depressed lines and show no intraumbilical supplementary apertures. However, the small depressions at the proximal margin of the last two flaps may be traces of two infralaminal openings. In both specimens, small and dense pores cross the wall surface, and prominent irregular ridges that mask the pores and appear to parallel the peripheral outline cover the inner spire and early chambers of the last whorl. These ridges gradually attenuate in the last 4-5 chambers until the surface of the last chamber is smooth.

Stratigraphic range. Paraticinella eubejaouaensis Zone (= Ticinella bejaouaensis Zone of Sigal, 1977), uppermost Aptian.

Genus Ticinella Reichel, 1950, emend. Brönnimann and Brown, 1956

Ticinella bejaouaensis Sigal, 1966

Holotype. (Sigal, 1966, pl. V, figs. 5-7), microslide F6 0887, case 11, MNHN in Paris. From the Diego well (Madagascar), core 56, $215.2 \mathrm{~m}$ depth, late Albian.

New description. Low trochospire that is only slightly elevated; 8 chambers in the last whorl, increasing gradually and regularly in size, initially globular, becoming slightly reniform in side view; sutures on spiral side gently curved in the early chambers, straight and radial between the last two; on umbilical side, early chambers are inflated, last four chambers become more triangular; sutures depressed, mainly straight and radial; umbilicus shallow, about onethird of the diameter; primary aperture is an interiomarginal low arch, umbilical-extraumbilical almost reaching the periphery; labial extensions short, two umbilical supplementary apertures bordered by a distinct rim; surface coarsely pustulose in the inner whorls and in the early chambers of the last whorl, smoother in the last ones; rugosities on wall surface consisting of fused pointed muricae that form very irregularly distributed, larger pustules surrounding large perforations $(>4 \mu \mathrm{m})$.

Remarks. Sigal identified Ticinella roberti in the same microslide F6 0887 (cases 1-3) as the holotype of $T$. bejaouaensis. These forms are smaller than the $T$. bejaouaensis holotype, they have 7 to 8 subglobular chambers in the last whorl that increase slower in size in spiral and umbilical views and faster in side view and become progressively thicker (reniform), and they have a rather narrow and deep umbilicus. The wall texture of $T$. bejaouaensis is similar to that of the associated $T$. roberti.

From the material deposited by Sigal in 1979 at the Fribourg Geological Institute, we picked two specimens of Ticinella roberti (Sigal's microslide 1, cases 14 and 15, the Diego well, depth $200.0 \mathrm{~m}$ ). From SEM analysis (Pl. 1, Figs. 2a-e; Pl. 4, Figs. 5a-c), these specimens of T. roberti possess the typical wall structure of the ticinellids: the pores are regularly spaced and $4-8 \mu \mathrm{m}$ in mean size; the wall surface is devoid of perforation cones but instead is encrusted and coarsely pustulose due to the irregular distribution of stout, overgrown muricae.

As already mentioned by Sigal (1966), the differences between the holotype of Ticinella bejaouaensis and the associated Ticinella roberti appear to be confined to a slightly higher number of chambers in the last whorl in the $T$. bejaouaensis holotype than in $T$. roberti. In addition, the short inner spire length of the holotype of $T$. bejaouaensis is similar to that of the oldest $T$. roberti individuals identified by Gandolfi (1942), while the much longer inner spire in the holotype of $T$. roberti (redrawn by Caron and Luterbacher, 1969) from younger layers suggests that its increasing length is related to the evolution of Gandolfi's species through time.

In conclusion, the holotype of Ticinella bejaouaensis falls reasonably within the variability of $T$. roberti, and so, in answer to questions raised by Moullade and others (2002), it should be considered an objective junior synonym of the latter. This synonymy may account for the poor record of T. bejaouaensis versus the very large, widespread record of $T$. roberti. In fact, besides the holotype, none of the several specimens illustrated in the literature is known so far to match the T. bejaouaensis holotype.

In the collection of Collignon and others (1979), deposited at the Museum in Paris, we also observed the two specimens identified by Sigal as Ticinella $\mathrm{cf}$. bejaouaensis (in Collignon and others, 1979, pl. 1, figs. 13-14) on the SEM plug: one specimen (pl. 1, fig. 13, spiral view) has 9-10 chambers, and the second one (pl. 1, fig. 14, umbilical view) has 7.5 chambers in the last whorl. The first specimen, in spite of a rather high inner spire, may fall within the Ticinella roberti variability. The specimen in plate 1 , figure 14 of Collignon and others (1979; umbilical view) is only weakly diagnostic of the T. bejaouaensis holotype. On the other hand, it appears close to Ticinella moulladei $\mathrm{n}$. sp. by having a wide and shallow umbilicus (see following). An inability to observe the other views (since the specimens are glued on the plug) prevents us from establishing to which of the species they are related. However, both specimens are different from the Tunisian paratype.

of Fig. 36.2a-c from Caron [1985], identified as Ticinella bejaouaensis), late Albian. Scale bars $=100 \mu \mathrm{m}$. 5a-b Ticinella moulladei n. sp., Caravaca, southeastern Spain, sample All 69.127 (printed from MC negatives), late Albian. Scale bars $=100 \mu \mathrm{m}$. 6a-c Ticinella roberti (Gandolfi, 1942), Diego well (Madagascar), core 53, level $200.0 \mathrm{~m}$, Sigal's slide 1, case 15, late Albian. Scale bars $=200 \mu \mathrm{m}$. a $=$ umbilical view; $\mathrm{b}=\mathrm{edge}$ view; $\mathrm{c}=$ spiral view. 
We confirm that the age of the type level at $215.2 \mathrm{~m}$ in the Diego well is early late Albian.

Ticinella moulladei $\mathrm{n}$. sp.

Pl. 3, Figs. 1a-d (holotype), 2a-c (paratype), and 3a-c to 5a-b

Description. From the material deposited by Sigal in 1979 at the Fribourg Geological Institute, we picked two socalled topotypes, identified as T. bejaouaensis by Sigal, out of his original material (microslide 4, case 9), which initially appeared similar to the holotype. Both specimens (see Pl. 4, Figs. 1a-d, 2a-c) possess a low spiral convexity, 8 and 9.5 globular chambers in the last whorl, respectively, they are loosely coiled, and the chambers increase very gradually in size. The sutures are depressed and straight on both sides, and the umbilicus is wide and shallow. The primary aperture is a low to low-medium arch that is umbilicalextraumbilical in position, almost reaching the periphery and accompanied by at least two to three clear umbilical supplementary apertures. The wall texture in the inner spire and early chambers of the last whorl is coarsely pustulose, as is the wall of $T$. roberti, with large pustules surrounding the pores. It becomes gradually smoother in the last two or three chambers, which is devoid of perforation cones. Perforations are regularly spaced, rather large $(4-8 \mu \mathrm{m})$, and similar in size to those of the other ticinellids (see $T$. roberti in P1. 1, Figs. 2a-e; Pl. 3, Figs. 6a-c).

Remarks. In addition to the Diego well (Madagascar), the same characters have been observed in three other specimens, collected by MC from Caravaca, Spain (courtesy of F. Allemann), which are associated with late Albian B. breggiensis. These are illustrated in Plate 3, Figures 3-5, including a specimen (Pl. 3, Fig. 4a-c) that was figured in Caron (1985, fig. 36.2a-c) as T. bejaouaensis. From SEM analysis, the wall structure in all these specimens is typical of the ticinellids.

This taxon resembles Paraticinella eubejaouaensis in gross morphology concerning the number of chambers in the last whorl, their gradual size increase, globularity, loose coiling in a low trochospire, wide umbilicus, and presence of straight, depressed sutures. This similarity may account for the lumping of the holotype and paratype of Sigal's (1966) Ticinella bejaouaensis into a single species. On the other hand, the presence of true umbilical supplementary apertures and the typical Ticinella wall surface prevent consideration of this taxon as congeneric with $P$. eubejaouaensis. It differs from Ticinella primula Luterbacher, 1963, with which it shares a flat trochospire, by having a larger size, more numerous chambers that are more loosely coiled, at least 8 and up to 10 chambers that gradually increase in size as added in the last whorl (instead of an average of 7 chambers), an umbilical area that tends to be larger, and a wall surface with strong ornamentation close to that of the advanced ticinellids (see Pl. 3). In contrast, the wall surface of $T$. primula is only slightly rugose.

This taxon differs from the coeval Ticinella roberti plexus by having a flat to very low, loosely coiled trochospire, a much larger and shallow umbilicus, and a very gradual increase in size of the globular chambers throughout the last whorl. It differs from Ticinella praeticinensis by the absence of a pinched margin. In conclusion, it is our opinion that the taxon described above belongs to a new species, here named Ticinella moulladei $\mathrm{n}$. sp.

Etymology. This species is named in honor of Prof. Michel Moullade, for his important, long-lasting contributions to Cretaceous planktonic foraminiferal taxonomy and biostratigraphy.

Size. Holotype maximum diameter $0.395 \mathrm{~mm}$, thickness $0.150 \mathrm{~mm}$; paratype maximum diameter $0.400 \mathrm{~mm}$, thickness $0.142 \mathrm{~mm}$.

Occurrence. It is associated with Biticinella breggiensis and Ticinella roberti in upper Albian strata from Madagascar and Spain.

Repository. Holotype (Micro-Unimi No. 1975, Pl. 3, Figs. 1a-d); paratype (Micro-Unimi No. 1976, Pl. 3, Figs. 2a-c) deposited in the Micropaleontological Collection, University of Milan, Dipartimento di Scienze della Terra "Ardito Desio," Italy.

Type locality. Madagascar, the Diego well, north of Mont-Raynaud, core 56, level $215.2 \mathrm{~m}$.

\section{CONCLUSIONS}

From the analysis of Sigal's type material, in agreement with Randrianasolo and Anglada (1998) and Moullade and others (2002), we confirm that the holotype and paratype of Ticinella bejaouaensis belong to two different species. In addition, Sigal's holotype of Ticinella bejaouaensis of late Albian age falls within the variability of Ticinella roberti and is considered to be a junior objective synonym.

Sigal's paratype of Ticinella bejaouaensis, elevated in rank to holotype of the species eubejaouaensis by Randrianasolo and Anglada, 1998, emended Moullade, 1966, has a latest Aptian age. Moreover, based on the different wall texture and the presence of expanded labial flaps lacking true supplementary apertures, the species eubejaouaensis cannot be included in the genus Ticinella. Therefore, we erect the new genus Paraticinella to accommodate the trochospiral individuals with a finely perforate wall, as occurs in Hedbergella trocoidea, accompanied by short imperforate ridges (rugosities) that parallel the equatorial periphery and umbilical flaps that lack true supplementary apertures.

A third species was observed associated with Ticinella roberti and Biticinella breggiensis in Madagascar and in Spain. This species belongs to the genus Ticinella based on the presence of true umbilical supplementary apertures and a typical Ticinella wall structure, while its gross morphology resembles Paraticinella eubejaouaensis. This new taxon is here named Ticinella moulladei $\mathrm{n}$. sp.

Finally, Paraticinella eubejaouaensis must replace Ticinella bejaouaensis as the index taxon for identifying the uppermost Aptian planktonic foraminiferal zone.

\section{ACKNOWLEDGMENTS}

The authors deeply thank Marie-Thérèse Vénec-Peyré for her warm hospitality during the visit of two of us (IPS, MC) at the Paris Museum and for her helpful observations of Sigal's paratype. The authors acknowledge the careful reviews and insightful comments by Brian Huber and Shulamit Lipson-Benitah. The authors would like to thank 
Agostino Rizzi (Istituto per la Dinamica dei Processi Ambientali, Consiglio Nazionale delle Ricerche, IDPACNR, Milan) for operating the SEM and Giovanni Chiodi (Milan) for technical support. Financial support of MIURCofin 2005 to IPS is acknowledged.

\section{REFERENCES}

Aguado, R., Castro, J. M., and de Gea, G. A., 1999, Aptian bioevents: an integrated biostratigraphic analysis of the Almadich Formation, Inner Prebetic Domain, SE Spain: Cretaceous Research, v. 20, p. 663-683.

Bellier, J.-P., and Moullade, M., 2002, Lower Cretaceous planktonic foraminiferal biostratigraphy of the western North Atlantic (ODP Leg 171B), and taxonomic clarification of key index species: Revue de Micropaléontologie, v. 45, no. 1, p. 9-26.

Bralower, T. J., Leckie, R. M., Sliter, W. V., and Thierstein, H. R., 1995, An integrated Cretaceous microfossil biostratigraphy, in Berggren, W. A., Kent, D. V., Aubry, M.-P., and Hardenbol, J. (eds.), Geochronology, Time Scales, and Global Stratigraphic Correlation, Special Publication 54: SEPM (Society for Sedimentary Geology), Tulsa, p. 65-79.

Brönnimann, P., and Brown, N. K., 1956, Taxonomy of the Globotruncanidae: Eclogae Geologicae Helvetiae, v. 48, p. $503-562$.

Caron, M., 1985, Cretaceous planktic foraminifera, in Bolli, H. M., Saunders, J. B., and Perch-Nielsen, K. (eds.), Plankton Stratigraphy: Cambridge University Press, Cambridge, p. 17-86.

, and Luterbacher, H.-P., 1969, On some type specimens of Cretaceous planktonic foraminifera: Contributions from the Cushman Foundation for Foraminiferal Research, v. 20, pt. 1, p. 23-29.

Collignon, M., Sigal, J., and Grekoff, N., 1979, L'Albien et le Cénomanien de Diégo (Madagascar) et ses faunes d'ammonites, foraminifères planctoniques et ostracodes: Eclogae Geologicae Helvetiae, v. 72, p. 215-249.

Dupeuble, P. A., 1979, Mesozoic foraminifers and microfacies from Holes 400A, 401 and 402A of the DSDP Leg 48, in Montadert, L., Roberts, D. G., and others. (eds.), Initial Reports of Deep Sea Drilling Project, v. 48: U.S. Government Printing Office, Washington, D.C., p. 451-473.

GandolfI, R., 1942, Ricerche micropaleontologiche e stratigrafiche sulla scaglia e sui flysch Cretacici dei dintorni di Balerna (Canton Ticino): Rivista Italiana di Paleontologia, Memoria, v. 4, p. 160.

Hay, W. W., DeConto, R. M., Wold, C. N., Wilson, K. M., Voigt, S., Schulz, M., Rossby Wold, A., Dullo, W.-C., Ronov, A. B., BALukHovsky, A. N., and SöDing, E., 1999, Alternative global Cretaceous paleogeography, in Barrera, E., and Johnson, C. C. (eds.), Evolution of the Cretaceous Ocean-Climate System, Special Paper 332: Geological Society of America, Boulder, CO, p. $1-47$.

HinZ, K., Winterer, E. L., and others., 1984, Initial Reports Deep Sea Drilling Project, v. 79: U.S. Government Printing Office, Washington, D.C., 934 p.

LeCKIE, R. M., 1984, Mid-Cretaceous planktonic foraminiferal biostratigraphy off central Morocco, Deep Sea Drilling Project Leg 79, Sites 545 and 547, in Hinz, K., Winterer, E. L., and others. (eds.), Initial Reports of Deep Sea Drilling Project, v. 79: U.S. Government Printing Office, Washington, D.C., p. 579-620.
Bralower, T. J., and Cashman, R., 2002, Oceanic anoxic events and plankton evolution: biotic response to tectonic forcing during the mid-Cretaceous: Paleoceanography, v. 17, no. 5, doi: 10.1029/2001PA000623, p. 29.

Lipson-Benitah, S., 2008, Phylogeny of the middle Cretaceous (late Albian-late Cenomanian) planktonic foraminiferal genera Parathalmanninella nov. gen. and Thalmanninella: Journal of Foraminiferal Research, v. 38, no. 2, p. 183-189.

- , and Almogi-Labin, A., 2000, Albian planktonic foraminifera from Israel: Bulletin of the Geological Survey of Israel, v. 86, p. $1-48$.

Longoria, J. F., 1974, Stratigraphic, Morphologic and Taxonomic Studies of Aptian Planktonic Foraminifera: Revista Espanola de Micropaleontologia, Madrid, Numero Extraordinario Diciembre 1974, $150 \mathrm{p}$.

Moullade, M., 1966, Étude Stratigrafique et Micropaléontologique du Crétacé Inférieur de la "Fosse Vocontienne": Documents du Laboratoire de Géologie, Faculté des Sciences, Lyon, no. 15, $369 \mathrm{p}$.

-, 1969, Sur l'importance des phénomènes de convergence morphologique chez les foraminifères planctoniques du Crétacé inférieur, in Brönnimann, P., and Renz, H. H. (eds.), Proceedings of the First International Conference on Planktonic Microfossils, Geneva, 1967, v. 2: E. J. Brill, Leiden, p. 460-467.

- Bellier, J. P., and Tronchetti, G., 2002, Hierarchy of criteria, evolutionary processes and taxonomic simplification in the classification of Lower Cretaceous planktonic foraminifera: Cretaceous Research, v. 23, p. 111-148.

Premoli Silva, I., and Sliter, W. V., 1999, Cretaceous paleoceanography: Evidence from planktonic foraminiferal evolution, in Barrera, E., and Johnson, C. C. (eds.), Evolution of the Cretaceous Ocean-Climate System, Special Paper 332: Geological Society of America, Boulder, CO, p. 301-328.

RandRianasolo, A., and Anglada, R., 1998, About Ticinella roberti var. bejaouaensis Sigal 1966 and Ticinella bejaouaensis Sigal emended Moullade 1966, in Joint Regional Meeting of IGCP Projects nos. 381 and 362, held in conjunction with the Cuban Geological Congress, Havana, Cuba, 24 March-1 April 1998: Geologia y Mineira '98, Memorias v. 2, p. 298, La Habana, (expanded abstract in SAMC News, v. 10, p. 26-28).

Reichel, M., 1950, Observations sur les Globotruncana du gisement de la Breggia (Tessin): Eclogae Geologicae Helvetiae, v. 42, p. 596-617.

Sigal, J., 1966, Contribution à une monographie des Rosalines. 1. Le genre Ticinella Reichel, souche des Rotalipores: Eclogae Geologicae Helvetiae, v. 59, p. 186-217.

_ 1977, Essai de zonation du Crétacé méditerranéen à l'aide des foraminifères planctoniques: Géologie Méditerranéenne, Aix-enProvence, v. 4, p. 99-108.

, 1979, Chronostratigraphy and ecostratigraphy of Cretaceous formations recovered on DSDP Leg 47B, Site 398, in Sibuet, J.-C., Ryan, W. B. F., and others. (eds.), Initial Reports of the Deep Sea Drilling Project, v. 47/2: U.S. Government Printing Office, Washington, D.C., p. 287-326.

Verga, D., 2004, The First Evolutionary Radiation of Planktonic Foraminifera in the Valanginian-Aptian Interval: Taxonomical, Biostratigraphical and Paleoecological Implications: Unpublished Ph.D. Thesis, University of Milan, 134 p., 83 pl.

Received 28 July 2008 Accepted 25 October 2008 